\title{
Running Between Catastrophe and Faith
}

\author{
Lynne Holdem
}

\author{
Psychotherapist, New Plymouth
}

\begin{abstract}
This paper offers reflection on the impact of near death experiences on consciousness, meaning making, identity, and our capacity to experience wholeness and aliveness. It suggests near death experiences may be opportunities for psychic growth and raises some possibilities about how this may occur. The author's own story of terror and survival whilst running from a tsunami, the impact on her mental state and relations with others, and the way this experience was symbolised and integrated is described. The subsequent expansion of emotional freedom and agency in her clinical work is illustrated with two case vignettes.
\end{abstract}

\section{Waitara}

He utu ka tau ki te taha kare-ā-roto, taha pūtaiao mai i te whakawhitinga i tētahi ahurei kope pātea ki tētahi hapori whakamau kope whiu. I muri mai i te mātakitakinga kōhungahunga i te haerērētanga i Āhia, e whakapae ana au nā te tikanga whakahaere whakaputa para a te kōhungahunga ka hōhonu kē ake te piri te pirihonga, ā, inā rongo te tamaiti i te pēnei o tōna mau ki tōna whāea ka mauri tau ake te atoato. Heoi anō, ko te mahi tautokonga mau kope whiu pea tō tātou whakapuranga kanohi inā te kore e whakaaro ake ki ngā tūpatonga ki te oranga hinengaro oranga tinana ki ngā rēanga o anamata, tae atu hoki ki a Papatuanuku.

Keywords: aliveness; trauma; death; faith; catastrophe; change

\section{Trauma and Healing - Some Literature}

Traumatic events and losses often produce psychological defences and anxieties constricting contact with reality and preventing emotional development. Aetiology, clinical examples, and technical implications for treatment are well documented by trauma specialists (Briere, 1992; Frederickson, 2013; Herman, 1992; Rothschild, 2000; van der Kolk, 2014). In the Jungian tradition, analyst Donald Kalsched recognised resistance as an attempt to protect a fragile self from further intrusion, assuring the

Holdem, L. (2014). Running between catastrophe and faith. Ata: Journal of Psychotherapy Aotearoa New Zealand, 18(2), 149-158. DOI:10.9791/ajpanz.2014.14 @ New Zealand Association of Psychotherapists Inc. 
survival of "that vital spark... so crucial for the experience of aliveness ...and to...'feeling real'”(Kalsched, 2013, p. 11). Following trauma, an archaic protector may close off meaningful connection between psychotherapist and patient or perpetuate the experience of catastrophe through unconscious re-enactments in the transference: "Each new life opportunity is mistakenly seen as a dangerous threat of re-traumatisation and is therefore attacked" (Kalsched, 1996, p. 5). Similarly, Symington (2007) vividly described narcissism as the traumatised state, a turning away from the life-giver: "So, the jelly and the god are two sides of one coin and both of them exclude the possibility of creative freedom" (p. 243).

Our patients are tyrannised by depression, flooded with affect, quaking with anxiety, numbed by addictions, dismembered by disassociation, and/or buried alive in schizoid withdrawal. Will we be able to make a connection with them and, if so, will that connection be a life-giving one?

\section{Surviving Catastrophe}

I will use a clinical vignette to demonstrate the challenges involved in making such a connection and the "coincidental" or "accidental" events that can ease the impasse. Throughout this article, all client names and identifying details have been changed.

As a beginning counsellor, I met Billy. Sexually abused and neglected as a child, she had a tough, promiscuous, funny, and aggressive persona, defending with dissociation, splitting, and disavowal a fragmented vulnerable core. Caught up in masochistic acts which flooded her with shame and rage, she turned against herself in suicidal threats. I was caught up in her dread, feeling helpless and intruded upon, possibly identifying with her early victim experiences. The transference-countertransference had a frightening sadomasochistic music. Used to being the good object for my clients, I felt out of my depth. As a summer break approached Billy escalated threats of suicide. Finally on the phone one day I was brought to my knees and told her that I could not stop her doing this terrible thing. That finally it was her decision.

During the summer break Billy discovered she had cancer, was operated on, and returned to therapy quite changed; she wanted to live. Instead of turning against herself, or being enslaved in sadomasochistic enactments, her will galvanised behind her own life project. It seemed possible for her to let go of dissociation and addictive behaviours and to think about feelings, examine projections, tolerate reactions, and risk knowing and being known, an experience of "surrender" as opposed to "submission" (Ghent, 1990, p.12). Encountering pain and the possibility of death amazingly seemed to free her from the grip of her self-care system (Kalsched,1966), breach the closed system (Fairbairn, 1996, p. 104) of her inner world and restore object seeking. Her suffering became authentic rather than neurotic.

Was my admission of helplessness in the face of her threats responsible for this healing? Previously, had my empathy seemed too self-denying, inauthentic, a case of “anxious oneness?” (Benjamin, 2007, p. 8). Intent on helping her, I had perhaps made my reality operative and induced shame at her aggressive impulses toward me. My admission of helplessness was a "reaching down into my subjectivity" (Benjamin, 2007, p. 21) and 
showed I got how she felt and could bear it. Benjamin describes this as the "third in the one... where (mother) contains catastrophic feelings because she knows they are not all there is, compassion based on the strength of our acceptance of frailty” (p. 22).

\section{A Traumatic Experience In Samoa: Run Ruby run!}

My favourite uncle called me Tusitala because I loved telling stories. Tusitala is the name the Samoans gave to Robert Louis Stevenson. The following story is about a time when I experienced a transformation; a loss of a comforting and containing function of my psyche. Ironically, this story starts in Samoa.

Towards the end of a lovely stay in Samoa I, my partner Tony and our two girls Ruby (14) and Vita (12) stayed in a fale in the friendly village of Saleopaga. One morning we woke up to a violent earthquake that shot us out of bed onto the beach. When the ground stopped shaking the children went back to bed, Tony went to the dining room to write in his diary, and I went to the toilet. When I returned I thought about a swim, as the water looked particularly flat and inviting. Two local men were talking animatedly and pointing out to sea. Looking out I saw a white line close to the horizon. "Run! Tsunami! Run! Run for your lives!” they shouted. The reef was suddenly exposed as the water was sucked out by the advancing wave.

Tony and I grabbed the children and began to run across the hard volcanic rock toward the steep escarpment about 30 meters beyond the village. Villagers and tourists ran with us and we could hear a terrible jet plane, the tsunami roaring behind us, as we ran. Time slowed. The sound and rhythm of my panting breath and heaving limbs merged with that of other runners so we were as one, a many legged mammal running in blind panic from a prehistoric predator.

Thankfully I could see Tony and Vita some way ahead and Ruby just ahead. "Why is she not running faster when she can?"At that moment Ruby turned, "Are you alright Mum?” She was holding herself back to stay near me. "Run Ruby run,” I called and away she went.

Up the escarpment we scrambled, taking hold of grass and rock. Halfway, we stopped to take in the scene below. In awed silence, arms around each other, we started to haltingly put into words the devastation. All gone, the little houses and trees. Cars floated in dark water trapped in the hollow where the village once stood, concrete foundations of the houses were exposed, and everywhere the stuff of our lives lay scattered or floated helplessly.

Young men jumped across rubble to rescue the injured and elderly. Young boys guided schoolchildren up the track to the top of the escarpment. One carried a tiny grandmother on his back. Others climbed the remaining coconut palms to harvest their bounty and distribute it among the clusters of survivors. A line of schoolchildren miraculously reappeared, when assumed dead. Girls embraced, lamenting. Tony returned to help wounded people and we climbed to the top to find shelter.

Eventually we were evacuated in a van. People from Apia had driven south to help. It was hard to leave. Villagers who had been so hospitable to us had nothing left from years of building up from subsistence. In Apia a Samoan family, owners of Le Spa, gave us a loving and nurturing environment in which to recover from shock. At night the 
aftershocks set dogs barking. I woke many times and looked at Tony, felt his warmth, breath on my face, and watched my girls sleeping with the wonder and tenderness I had felt at their births. We had entered a kind of paradise. During the next weeks there was no conflict or pettiness, every conversation was threaded with gold. It was enough to look at the earth and each other and to feel the wonder of life in us and around us.

\section{Existential Crisis}

Shock had radically opened my here and now experiencing and made me vividly aware of participation in existence, connection with all things, and the value of being alive. An ancient book on yoga contains the following:

In conditions like terror, keen curiosity or flight from the battlefield, whenever the ordinary normal consciousness receives a sudden jolt or shock, it is thrown back to its inmost depth and comes in contact with spanda, the pulsation of the deepest consciousness, the source of his being. It is a sudden and momentary state, but if the person is wide awake, he clings to it. From that moment, his life is completely changed. He becomes spiritually oriented; his energies are released from the hold of the trivialities of life and are free to dive into the deeper recesses of consciousness. (Singh, 1979, p. 106)

As a young girl I had a similar experience of myself dissolving into nature, feeling part of everything; an experience of terror and of bliss. Awareness of time contracted and expanded. Both experiences evoked a kind of joy in being alive. Both were difficult to integrate into "ordinary" life. "Recovery" not possible, we let ourselves be changed.

In Civilization and its Discontents, Freud examined Roland's assertion that he felt always a sensation of "eternity, a feeling of something limitless, unbounded ... oceanic" (1930, p. 5). Freud suggested this was a relic of an "early phase of ego-feeling" (p. 9). He explained with metaphor that everything past may be preserved in mental life, asking his reader to imagine a city like Rome but with all the buildings from every era, ancient and modern, visible to an observer. Shock may expose earlier ego states, like an earthquake unearths a previous building foundation. These then co-exist with more recent phases of ego feeling. This describes how I felt after my return to New Zealand. Like the observer in Freud's imaginary Rome, I could shift my gaze and observe a more regressed experience of my objects and my surroundings or turn away and restore a more familiar and recent experience of them.

Ghent described the "liberation and expansion of the self as a corollary of letting down of defensive barriers" (1990, p. 1). In her exploration of creativity, Marion Milner described moments in which there is a "plunge into no-differentiation which results (if all goes well) in a re-emerging into a new division of the me-not-me" (as cited in Ghent, 1990, p. 3). Certainly, after the tsunami, my defenses were not operating as previously and I worked in dreams, both waking and sleeping, to symbolise the experience. For Winnicott, regression carried "the hope of a new opportunity for an unfreezing" (Winnicott as cited in Ghent, 1990, p. 2). All new experience needs to be integrated and involves a choice for "refusal ... 
(or) embracing the life-giver, an acceptance of the self” (Symington, 2007, p. 212).

Attempting to understand my mental state lead me to Eigen's “Toward Bion's starting point: Between catastrophe and faith" (1985). The title alone provided hope that I might move through dread and restore faith. What was helpful in Eigen's paper was his emphasis on the self's innate rhythm "to fall apart and come together" (p. 2); making explicit the value of paranoid schizoid breaking apart depressive states in keeping one's relationship to the whole object fresh. When "free play of Paranoid-schizoid $\leftrightarrow$ Depressive occurs through Faith in O" (Eigen,1985, p. 9) a dynamic of falling to pieces and coming together enables us to receive the impact of emotional reality and to evolve with it, gathering in and reuniting elements that have been fragmented, enabling us to affirm love while knowing hate.

Without awareness of catastrophe we lose our sensitivity to ourselves. Eigen suggested we attend with an alive waiting (1985, p. 7); an uncomfortable yet open state that does not exclude what is real but unknown. In Eigen's reading of Bion, faith in $\mathrm{O}$ does not make reality more palatable, rather "it enables us to know and remember less dissociatively" (1985, p. 7) and accept not knowing. According to Ogden, "We trade freedom for safety, aliveness for certainty" (1999, p. 18). Defences thus create barriers to experiencing helplessness and deprive us of sensitivity and aliveness. Unless we allow oscillation between paranoid schizoid and depressive states, we can get stuck.

\section{Meaning Making: Can My Father Carry Me Over?}

Back in our seaside home I was afraid of the sea. I felt small and helpless; the toy of a capricious and vengeful God. That refuge of nature, always so benign and restorative, had become a source of dread. Since I long ago abandoned any belief in a personal God it was

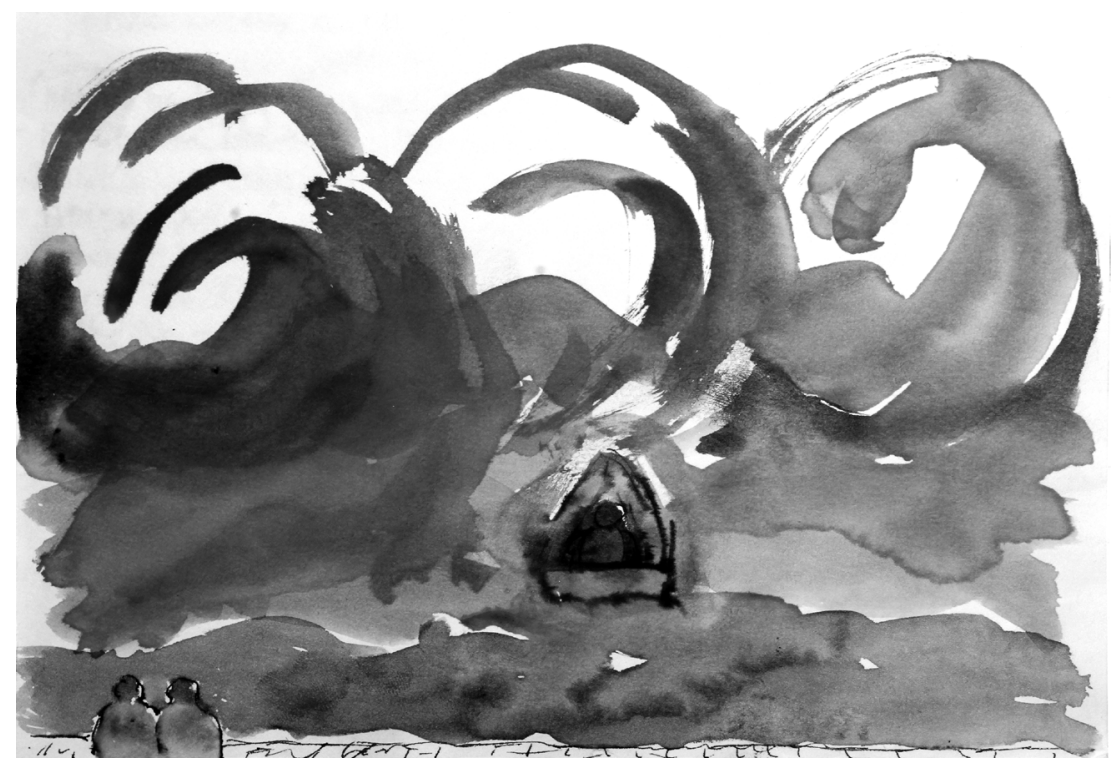


surprising to find myself thinking in this rather primitive way.

In Civilization and its Discontents Freud equated religious need with "longing for the father" (1930, p. 9). Instinctively I turned to my ideal object (Fairbairn, 1996) recalling memories of him. My father often took me fishing in his small boat off the South Taranaki coast at Patea. It is a treacherous coast where the weather changes suddenly. To re-enter the harbor you have to cross the bar. Above is a drawing I made in 1988, three years after my father's death. He would tell me, "You watch the wave behind Lindy. If it looks like its going to break in the back of the boat tell me and I'll give her the juice." I wondered if he was joking; being scared and being laughed at were close companions in our family. Risk did not occur to me. I felt safe in my father's hands and this was projected into my experience of Nature: someone watching over me. Experiences of the sea were redolent with memories of father: when young he made my bed into a boat to journey to morning, in adolescence I spent hours with him fishing by rivers and sea. He was the "unconscious boundless supporting other" (Eigen, 2009, p. 25).

It could be viewed that in remembering my father I was regressively attempting to restore an idealisation of him in order to avoid a sense of helplessness. Since these memories also evoked feelings of guilt for damage I had done to him, awareness of his vulnerability (and my own), and urges to atone, I think, in fact, I was repairing damage to my internal object, mourning, and accepting loss.

\section{Integration}

My supervisor helpfully stated that I had survived and did well to get my family out. This addressed guilt and moderated manic repair. I am now aware of mortality and more conscious of being alive and embodied. Existence is fragile but this also brings a greater appreciation of living. As a result of these changes in me, I am naturally more aware of states of aliveness and deadness in my patients. I also have more confidence in my power of agency, resulting in greater ability to effect "breaches of the closed system of the patient's inner world ... to make this world accessible to the influence of outer reality"(Fairbairn, 1996, pp. 102-103) I trust I can repair breaks in attunement and I can dare to be more active in relationship. Regression has developed my capacity and appreciation for mature dependence (Fairbairn, 1952, p. 34). I also experience stronger attachment-seeking impulses and feel joys and disappointments more intensely. Similarly, I am less likely to collapse in the face of aggression and more able to summon aggression on my own behalf. Some qualities I associate with my father have become available to me: a quick ability to read a situation and the aggression to meet and match what comes towards me, to detect "bullshit". This strengthens my holding of patients so they feel safer to use me. A moment with a more recent patient illustrates this.

\section{Coming Alive in the Work}

Two moments come together in my mind as questions and statements, one from the tsunami, the other from my childhood: "Are you all right Mum? Am I all right Mum? There's a big wave about to break. Give it the Juice, Dad. Run Ruby Run.” 
In Colin McCahon's 1976 painting Scared, "I am scared” is scrawled in white on a black surface. Underneath and separated by a thin, interrupted white line are the words "I stand up". McCahon links fear and courage in an unsteady equation, just as Bion (1985) links catastrophe and faith in O. Each requires the other.

According to Sullivan (2014), the haka (vigorous dance) “Ka mate! Ka mate!” by Te Rauparaha (c. 1820) "depicts a journey from a pit in darkness representing death to a sunlit place representing life”. Running from his enemies, Ngati Te Aho, Te Rauparaha hid in a kumara pit. Te Rangikoaea, the wife of his protector Te Wharerangi, sat above him shielding him from the Ngati Te Aho seeking revenge. As Te Rauparaha listens to his enemies come closer he must face the possibility of imminent defeat and humiliation. As they leave he celebrates a triumphant survival. Thus he is born again into the world of light. Kua whiti te ra! (The sun shines).

Now to the clinical vignette. Like the earlier client Billy, Antoinette's personality was shaped by significant trauma; episodes of life-threatening domestic terrorism. A partner was shot dead in front of her and, vulnerable to paranoid fantasies, she regularly deadened her rage and pain by self-medication with prescription drugs. In early sessions she talked of distressing experiences in a flat dissociated way and would withdraw, staring into empty space. I helped her connect up and think about her feelings, recognise triggers, and find ways to come back to here and now experiencing. Lately she had been showing signs of coming alive a little, taking an interest in study and volunteer-work.

After the Christmas break, she is pale, quiet and strained. She has missed several sessions and crashed her car into a bridge after a series of unwanted and intrusive visits from her father. I am affected by her deadened mood, disappointed that she has retreated into isolation and that another male persecutory figure threatens.

During the session after the Christmas break, I remembered two incidents. Once when Antoinette's mother did not visit as expected, Antoinette displaced her rage in taking an axe to her car. She was puzzled by this, and made no link to her feelings about her mother's non-appearance. Unable to bear feeling angry or upset, she turned these feelings against herself by attacking something she valued. After this episode she also went "dead" for a while, isolated herself from others, and did not attend sessions. When she did attend, we were able to think together about her mother's absence as a screen memory of the lack of her presence and protection in her early life, and her attack on the car as a way of protecting her mother in order to keep her good in her mind. I asked her to think about the two times she had smashed her car, first with an axe and later by crashing it, and the feelings of frustration she had been experiencing with her mother and father at the time. She was able to link these mentally, to see that she had turned rage at her outer objects against herself, but the atmosphere remained cold and deathly.

I also remembered a dream she had brought to therapy a year earlier. In the dream she is living with her dead ex-partner and another dead man. She is happy but a voice tells her she needs to cross the road and live in another house. This memory of her dream, like a haka, seems to "stiffen (my) sinews ... summon (my) blood" (Karetu, 1993, cited in Sullivan, 2014); “Give her the juice, Lindy. Run Antoinette Run!” Imaginatively, I position myself across the road in the house of the living, lean forward in my chair, and say, "Antoinette, you are alive. It's good to be alive when you are alive. You are alive, living and 
partly living' (Eliot, 1935, p. 19). Come across the road to the house of the living!" This invitation was delivered with sufficient power and liveliness that it penetrated the resistance of her dissociative defences. Benjamin would describe this as "primary affectively resonant communication" (2007, p. 23).

Colour came to her face, she looked into my eyes and was present and alive. In the past, I do not think I would have been so active. I might have joined her collapsed, dissociative state or been worried about leading the patient, obstructed by my superego.

Next week I am surprised by her liveliness, colour, and movement. She talked to the police and her father had stopped visiting. She had found her own "will and power" (Ghent,1990, p. 7). Ghent described a deeper yearning of masochistic activity as a longing to be reached and known, "The individual then becomes free to use ... her own motility to discover and be discovered" (p. 5). Momentarily at least, Antoinette seems to have surrendered her identification with her dead partner and joined the living.

\section{Conclusion}

Through my personal story, clinical vignettes, and reference to the literature, I have explored how the emotional impact of near death experiences can penetrate defences, open up the closed system of our inner world, and expose earlier ego states to consciousness. These experiences can be integrated through mourning, new symbol formation, and by oscillations between paranoid schizoid and depressive positions. Falling apart and coming together thus free us to encounter both self and object "with all one's heart, with all one's soul, and with all one's might" (Eigen, 1981, p. 1). For me, surviving a tsumani and "surviving" the subsequent effects of the trauma helped differentiate authentic and neurotic suffering, bringing more emotional freedom, agency, and confidence in my clinical work.

\section{Acknowledgements}

A Psychosynthesis colleague, John Kingston, supplied the Vijnanabhairava reference. Discussions with Crispin Balfour regularly challenge and contribute to my thinking.

\section{References}

Benjamin, J. (2007). Intersubjectivity, thirdness, and mutual recognition. Retrieved January 20, 2015, from The Institute of Contemporary Psychoanalysis: http://icpla.edu/wp-content/ uploads/2013/03/Benjamin-J.-2007-ICP-Presentation-Thirdness-present-send.pdf

Briere, J. (1992). Child abuse trauma: Theory and treatment of the lasting effects. London, UK: Sage Publications.

Eigen, M. (1981). The area of faith in Winnicott, Lacan and Bion. The International Journal of Psycho-Analysis, 62, 413-433.

Eigen, M. (1985). Towards Bion's starting point: Between catastrophe and faith. The International Journal of Psychoanalysis, 66, 321-330. 
Eigen, M. (2009). Flames from the unconscious: Trauma, madness and faith. London, UK: Karnac Books.

Eliot, T. (1935). Murder in the Cathedral. New York, NY: Harcourt Brace \& Co.

Fairbairn, W. (1996). On the nature and aims of psychoanalytic treatment. In D. Scharff (Ed.) (pp. 98-111). Object relations theory and practice: An introduction. Lanham, MD: Rowman \& Littlefield.

Frederickson, J. (2013). Co-creating change. Kansas City, KS: Seven Leaves Press.

Freud, S. (1930). Civilization and its discontents. London, UK: Hogarth Press.

Ghent, E. (1990). Masochism, submission, surrender: Masochism as a perversion of surrender. Retrieved January 29, 2015, from www.wawhite.org/uploads/PDF/E1f_9\%20Ghent_E_ Masochism.pdf

Herman, J. (1992). Trauma and recovery . London, UK: Pandora.

Kalsched, D. (1996). The inner world of trauma: Archetypal defences of the personal spirit. New York, NY: Routledge.

Kalsched, D. (2013). Trauma and the soul. New York, NY: Routledge.

McCahon, C. Scared.(1976). [Painting] Wellington, Auckland: Museum of New Zealand Te Papa Tongarewa.

Ogden, T. (1999). Reverie and interpretation:Sensing something human. London, UK: Karnac Books.

Rothschild, B. (2000). The body remembers. New York, NY: Norton \& Co.

Singh, J. (1979). Vijnanabhairava or Divine Consciousness. Delhi, India: Motilal Banarsidass.

Sullivan, R. (2014). Ka Mate Ka Ora. Retrieved from: www.nzepc.auckland.ac.nz/kmko/o1/ka mateo1_sullivan.asp

Symington, N. (2007). Becoming a person through psychoanalysis. London, UK: Karnac Books. van der Kolk, B. (2014). The body keeps the score. New York, NY: Viking.

Winnicott, D. (1955). Metapsychological and clinical aspects of regression within the psychoanalytic set-up. International Journal of Psychoanalysis, 36, 16-26.

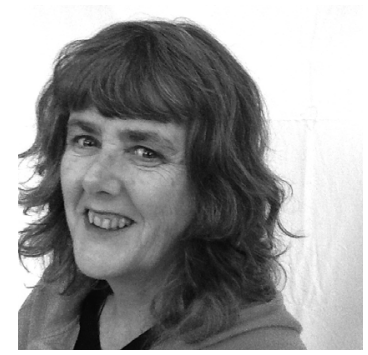

Lynne Holdem began training in counselling and psychotherapy with the Institute of Psychosynthesis NZ in 1989. Prior to this she was a teacher of English and Drama. Since joining NZAP in 2001 and becoming a full member in 2008 she has continued learning and expanding the base of her practice by reading in psychoanalysis as well as maintaining her interests in literature, social innovation, and spirituality. In 2003 Lynne moved from Auckland to New Plymouth, introducing psychotherapy to that small city and gradually building a general practice from the ground up. She has been involved with Supporting Families in Mental Illness Taranaki for many years, currently as manager. In that capacity she has been running a pilot program for children of parents with a mental illness or addiction (COPMIA). Supported by the NZAP study fund, she recently attended a Circle of Security training and she is endeavouring to include an 
attachment focus into the parent group she runs in tandem with the children's COPMIA group. She also works with Vivian Hutchinson to support social innovation and active citizenship through Community Taranaki. Contact details: lynneholdem@gmail.com 